\title{
KAJIAN TENTANG PERILAKU KEJAHATAN DAN PENYIMPANGAN SEKSUAL DALAM SUDUT PANDANG SOSIOLOGIS DAN HUKUM POSITIF INDONESIA
}

\author{
Andin Martiasari \\ Universitas 17 Agustus 1945 Banyuwangi \\ Jl. Adi Sucipto Nomor 26, Banyuwangi \\ Telp.(0333) 411248, Fax. (0333) 416440. \\ Email : martia.andin11@gmail.com
}

\begin{abstract}
Sexual deviation is an inappropriate act or sexual behaviour to be carried out to get sexual pleasure improperly. This behaviour is psychological or psychiatric, such as experience in chilhood, from the environtment and genetic factor that are associated with the social context and local moral standards. Deviant behaviour can be analyzed using sociologycal theories that explain the causes of sexual deviations, clarify the notion of the law and everything that stands behind the symptoms of public order in society as a contribution of law enforces to evaluate the effectiveness of the law in society. The regulations of sexual deviation in Indonesian positive law can be found in the criminal code, namely Adultery Article 284 of the criminal code, Sexual article 285, intercourse with woman in a state of unconsciousness and Article 286, and intercourse with woman who are not old enough in Article 287. More severe sanction, namely ratification goverment regulation in lieu of Law Number 1 Year 2016 concerning the second amandement to law number 23 of 2002 wich was previously updated in law number 35 of 2014 concerning child protection.
\end{abstract}

Keywords: Sexual Deviation, The Law Sociology, Legislation

\begin{abstract}
ABSTRAK
Perilaku penyimpangan seksual yang terjadi dewasa ini, dapat menggerogoti moral dan akhlak masyarakat, melanggar hak asasi manusia, dan menjadi permasalahan serius berkaitan dengan masalah sosial, hukum, agama, yang cepat atau lambat akan menghantarkan negara, khususnya generasi muda pada gerbang kehancuran. Dalam jurnal ini dibahas kajian secara sosiologis terhadap perilaku kejahatan dan penyimpangan seksual yang terjadi di masyarakat dan solusi terhadap penyimpangan seksual dan pengaturannya dalam hukum positif Indonesia. Perilaku menyimpang dapat di analisis menggunakan teori-teori sosiologi yaitu teori anomi, teori sosialisasi, teori labeling, dan teori kontrol sosial, yang menjelaskan penyebab terjadinya penyimpangan seksual. Pengaturan penyimpangan seksual dalam hukum positif Indonesia ditemukan pada KUHP yaitu Perzinahan pasal 284 KUHP, Persetubuhan Pasal 285, persetubuhan dengan perempuan pingsan dan tidak berdaya Pasal 286, dan persetubuhan dengan perempuan belum cukup umur pada Pasal 287. Selain itu Peraturan Pemerintah Nomor 1 Tahun yang sebelumnya diperbarui dalam Undang-Undang Nomor 35 Tahun 2014 tentang Perlindungan Anak.
\end{abstract}

Kata kunci: Penyimpangan seksual, Sosiologi Hukum, Peraturan Perundang-undangan.

\section{PENDAHULUAN}

Manusia sesuai dengan kodratnya sebagai makhluk sosial cenderung hidup berkelompok, berkumpul dengan manusia yang lain membentuk sebuah komunitas masyarakat. Kehidupan berkelompok tersebut 
terproses melalui interaksi antar anggota masyarakat, dengan adanya norma-norma atau aturan-aturan yang menjadi pedomannya sehingga tercipta kehidupan yang tertib, teratur sesuai dengan tujuan yang dicitacitakan.

Terhadap perilaku yang tidak sesuai dengan hukum, maka hal ini disebut juga penyimpangan perilaku yang akan merugikan masyarakat banyak, dimulai dari hal-hal kecil atau ringan sampai pada yang berat. Masalah generasi muda pada umumnya ditandai oleh dua ciri yang berlawanan, yaitu keinginan untuk melawan (misalnya dalam bentuk radikalisme, delinkuensi dan sebagainya) dan sikap apatis (misalnya sikap perlawanan terhadap generasi tua). Apabila seseorang mencapai usia remaja, maka secara fisik dia telah matang, tetapi untuk dapat dikatakan dewasa dalam arti sosial, remaja tersebut perlu banyak belajar mengenai nilai dan norma-norma dalam masyarakat. B. Simandjutak, kejahatan merupakan suatu tindakan anti sosial yang merugikan, tidak pantas, tidak dapat dibiarkan, yang dapat menimbulkan kegoncangan dalam masyarakat ${ }^{1}$. Kejahatan seksual yang paling banyak terjadi saat ini adalah pelecehan seksual dan perkosaan.

Penyimpangan seksual pada anak sendiri didefinisikan sebagai suatu tindakan perbuatan pemaksaan untuk melakukan hubungan seksual maupun aktifitas seksual lainnya, yang dilakukan oleh orang dewasa terhadap anak anak baik laki-laki maupun perempuan, akan tetapi umumnya adalah anak perempuan dibawah 18 tahun. ${ }^{2}$ Penyimpangan seksual dapat juga diartikan sebagai bentuk perbuatan yang mengabaikan nilai dan norma yang melanggar, bertentangan atau menyimpang dari aturan-aturan hukum.

Sosiologi hukum sebagai ilmu yang berhubungan langsung dengan masyarakat merupakan jembatan untuk menjelaskan pada ilmu hukum bahwa persoalan hukum bukanlah persoalan yang berhenti dengan diaturnya suatu obyek, tetapi dapat dijelaskan dari pra proses, proses, sampai hasil dari proses dan evaluasi. ${ }^{3}$ Kajian tentang perilaku menyimpang dipelajari oleh sosiologi karena berkaitan dengan pelanggaran terhadap norma-norma sosial dan nilai-nilai kultural yang telah ditegakkan oleh masyarakat. Selain itu, melalui teori dan hasil-hasil penelitian yang dikembangkannya, sosiologi membantu masyarakat untuk dapat menggali akar-akar penyebab terjadinya tindakan menyimpang, sehingga dipelajari pula kajian tentang lembaga kontrol sosial dan efektivitasnya dalam mencegah terjadinya tindakan tersebut.

Perilaku penyimpangan seksual tersebut tidak dapat dianggap remeh, karena perilaku

\footnotetext{
${ }^{1}$ Simandjutak. B. dan Pasaribu, Kriminologi, Bandung; Tarsito, 1984. HIm 45

${ }^{2}$ Katjtaasungkana, Penyalahan Seksual Pada Anak, Jakarta; Mitra Wacana, 2006. Hlm. 14

${ }^{3}$ Saifullah, Refleksi Sosiologi Hukum, Bandung; Rafika Aditama, 2010. Hlm. 8
} 
tersebut dapat menggerogoti moral, serta akhlak masyarakat. Penggunaan ilmu sosiologi dapat memperjelas pengertian hukum dan segala sesuatu yang berdiri di belakang gejala-gejala ketertiban umum dalam masyarakat. Persoalan dalam masyarakat itu akan diamati, dicatat dan dijelaskan, dalam kapasitasnya sebagai pengamat dan teoritisi, sebagai acuan para penegak hukum untuk mengevaluasi efektivitas berlakunya hukum di masyarakat. Partisipasi aktif dari masyarakat maupun para penegak hukum dalam menanggulangi penyimpangan seksual ini sangat diperlukan, mengingat penyimpangan seksual dalam bentuk apapun tidak hanya melanggar hak asasi manusia, namun sudah menjadi permasalahan serius berkaitan dengan masalah sosial, hukum dan agama, yang cepat atau lambat akan menghantarkan negara, khususnya generasi muda pada gerbang kehancuran. Berdasarkan uraian latar belakang di atas, penulis tertarik untuk mengangkat tema "KAJIAN TENTANG PERILAKU KEJAHATAN DAN PENYIMPANGAN SEKSUAL DALAM SUDUT PANDANG SOSIOLOGIS DAN HUKUM POSITIF INDONESIA”.

Secara teoritis, manfaat yang akan didapatkan dari penelitian ini adalah untuk menambah wawasan ilmu pengetahuan dimana hasil penelitian ini diharapkan dapat menjadi bahan informasi dan referensi dalam bidang ilmu hukum, dan manfaat praktisnya adalah sebagai sumbangsih pemikiran untuk para masyarakat pada umumnya, akademisi dalam mempelajari perilaku penyimpangan seksual, dan praktisi hukum dalam mengevaluasi efektivitas berlakunya hukum di masyarakat.

Penelitian ini dilakukan bertujuan untuk mengetahui bagaimana sosiologi hukum menjelaskan perilaku kejahatan dan penyimpangan seksual yang terjadi di masyarakat berdasarkan teori-teori yang ada, untuk mengetahui solusi penyimpangan seksual ditinjau dari kajian sosiologis dan pengaturannya dalam hukum positif Indonesia, gan guna menambah wawasan dan ilmu pengetahuan pembaca sekalian, khususnya dalam bidang ilmu hukum.

Berdasarkan latar belakang masalah diatas, maka penulis memfokuskan penelitian ini pada bagaimana kajian secara sosiologis terhadap perilaku kejahatan dan penyimpangan seksual yang terjadi di masyarakat?, Bagaimana solusi terhadap penyimpangan seksual ditinjau dari kajian sosiologis dan pengaturannya dalam hukum positif Indonesia?

\section{PEMBAHASAN}

\section{Kejahatan dan Penyimpangan Seksual}

Acapkali dibedakan antara dua macam persoalan, yaitu masalah masyarakat (scientific or sicietal problem) dengan problema sosial (ameliorative or social 
problems). ${ }^{4}$ Masalah masyarakat berarti gejala-gejala yang timbul dalam kehidupan bermasyarakat, sedangkan problema sosial menganalisis gejala abnormal yang terjadi untuk mencari solusi bahkan menghilangkannya. Suatu kejadian yang merupakan masalah sosial belum tentu mendapat perhatian yang sepenuhnya dari masyarakat. Sebaliknya, suatu kejadian yang mendapat sorotan masyarakat, belum tentu merupakan masalah sosial. ${ }^{5}$ Kepincangankepincangan yang dianggap sebagai masalah sosial oleh masyarakat tergantung dari system nilai masyarakat tersebut. Beberapa persoalan yang dihadapi oleh masyarakat pada umumnya sama, misalnya yang berkaitan dengan kemiskinan, kejahatan, disorganisasi keluarga, masalah generasi muda dalam masyarakat modern pelanggaran-pelanggaran terhadap norma-norma masyarakat, dan sebagainya. Penulis membatasi penelitian ini pada point kejahatan, dan masalah generasi muda dalam masyarakat modern, khususnya tentang penyimpangan seksual.

Penyimpangan adalah sikap tindak di luar ukuran atau kaidah. Deviasi atau penyimpangan diartikan sebagai tingkah laku menyimpang dari tendensi sentral atau ciriciri karakteristik rata-rata dari kebanyakan populasi. Deviasi seksual ialah gangguan ke arah atau tujuan seksual, karena mendapatkan kepuasan seksualnya dengan cara keluar dari kebiasaan. Penyebab terjadinya kelainan ini bersifat psikologis atau kejiwaan, seperti pengalaman sewaktu kecil, dari lingkungan pergaulan, dan faktor genetik. Bentuk-bentuk penyimpangan seksual sangat beragam. Berikut ini beberapa macam bentuk gangguan seksual.

1. Sadisme seksual termasuk kelainan seksual.

Adalah pemuasan nafsu seksual dengan jalan menyakiti lawan jenisnya bahkan tidak jarang sampai meninggal dunia.

\section{Masochisme}

kepuasan seksual dengan memperlihatkan alat kelamin mereka kepada orang lain. Bila korban terkejut, jijik dan menjerit ketakutan, ia akan semakin terangsang.

3. Voyeurisme

Penderita kelainan ini akan memperoleh kepuasan seksual dengan cara mengintip atau melihat orang lain yang sedang telanjang, mandi atau bahkan berhubungan seksual.

\section{Fetishisme}

Fatishi berarti sesuatu yang dipuja. Jadi pada penderita fetishisme, aktivitas seksualnya disalurkan melalui bermasturbasi dengan $\mathrm{BH}$ (breast

\footnotetext{
${ }^{4}$ Koenig Samuel, Man and Society, New York; Baners \& Nobel inc, 1957. Hlm. 302.

${ }^{5}$ Soekanto Soerjono, Sosiologi Suatu Pengantar, Jakarta; Rajawali Pers, 2007 Hlm. 318
} 
holder), celana dalam, atau benda lain yang dapat meningkatkan hasrat seksual hingga mendapatkan kepuasan.

5. Pedophilia/Pedophil/Pedofilia/Pedofil

Adalah orang dewasa yang yang suka melakukan hubungan seks / kontak fisik yang merangsang dengan anak di bawah umur.

6. Bestially

Yaitu melakukan hubungan seks dengan binatang seperti kambing, kerbau, sapi, kuda, ayam, bebek, anjing, kucing, dan lain sebagainya.

7. Incest

Adalah hubungan seks dengan sesama anggota keluarga sendiri non suami istri seperti antara ayah dan anak perempuan dan ibu dengan anak lakilakinya.

8. Necrophilia/Necrofil

Adalah orang yang suka melakukan hubungan seks dengan orang yang sudah menjadi mayat / orang mati.

9. Zoophilia

Zoofilia adalah orang yang senang dan terangsang melihat hewan melakukan hubungan seks dengan hewan.

\section{Sodomi}

Sodomi adalah pria yang suka berhubungan seks melalui dubur pasangan seks baik pasangan sesama jenis (homo) maupun dengan pasangan perempuan.

\section{Frotteurisme/Frotteuris}

Yaitu suatu bentuk kelainan sexual di mana seseorang laki-laki mendapatkan kepuasan seks dengan jalan menggesekgesek/menggosok-gosok alat kelaminnya ke tubuh perempuan di tempat publik / umum seperti di kereta, bis, dan sebagainya.

\section{Gerontopilia}

Adalah suatu perilaku penyimpangan seksual dimana pelaku jatuh cinta dan mencari kepuasan seksual kepada orang yang sudah berusia lanjut (nenek atau kakek).

\section{Homoseksual}

Merupakan kelainan seksual berupa disorientasi pasangan seksualnya. Disebut gay bila penderitanya laki-laki dan lesbi untuk penderita perempuan. ${ }^{6}$

\section{Faktor Penyebab Kejahatan dan Penyimpangan Seksual serta Akibatnya}

Faktor yang menyebabkan kejahatan dan penyimpangan seksual dapat berasal dari dalam diri pelaku atau intrinsik, atau dari luar diri pelaku atau ekstrinsik. Faktor intrinsik ialah faktor-faktor keturunan misalnya ketidak seimbangan hormon esterogen dalam tubuh pria sehingga mendekati karakteristik wanita, kelainan fisik sejak lahir. Sedangkan

\footnotetext{
${ }^{6}$ Sulistiani, Siska, Lis, Kejahatan dan Penyimpangan Seksual, Bandung; Nuansa Aulia, 2010. Hlm. 8.
} 
faktor ekstrinsik mencakup adanya kerusakan-kerusakan psikis dan fisik disebabkan oleh pengaruh-pengaruh luar misalnya pengaruh film, video, internet yang berisi muatan pornografi yang mendorong adanya perilaku penyimpangan seksual, atau oleh adanya suatu interaksi pengalaman dengan lingkungan sekitar yang sifatnya traumatis. Menurut Sumiati, faktor Internal dan ekseternal penyimpangan seksual dapat berupa:

a. Meningkatnya libido seksual, misalnya pada sebagian remaja yang tidak bisa menahan hasrat atau libidonya, sehingga terjadi perilaku seks;

b. Pengetahuan seks yang sangat kurang, sehingga remaja melakukan perilaku seks tanpa mengetahui sebab dan akibatnya dan salah dalam mengartikan perilaku seks;

c. Pengembangan kontrol diri yang cukup terhadap tingkah laku;

d. Perkembangan emosi dan moral sangat mempengaruhi remaja untuk berprilaku seks;

e. Kemauan atau keinginan yang mendalam sangat mempengaruhi remaja berprilaku seks;

f. Agama dan keimanan agama dan keimanan yang kurang, sangat mempengaruhi remaja untuk berprilaku seks.
Sedangkan Faktor Eksternal bisa berupa :

a. Sikap orang tua yang otoriter (mau menang sendiri, selalu mengatur, semua perintah harus diikuti tanpa memperhatikan pendapat dan kemauan anak) akan sangat berpengaruh pada perkembangan kepribadian remaja;

b. Sumber informasi (media) sangat mempengaruhi remaja untuk berprilaku seks, karena dengan adanya media memudahkan remaja untuk melihat adegan porno yang membuat remaja juga ingin melakukannya.

c. Lingkungan adalah faktor yang paling besar memunculkan penyimpangan seks;

d. Sosial budaya remaja yang berada dalam perubahan fisik dan emosi serta perubahan yang paling menonjol pada remaja adalah ketika dia menyukai lawan jenis, karena remaja ingin diterima, diperhatikan dan dicintai oleh lawan jenis serta teman sekelompoknya;

e. Pendidikan seks sangat mempengaruhi remaja untuk berprilaku seks, karena bagi remaja yang tidak mengetahui apa itu seks, kapan waktu untuk melakukannya, sehingga dari apa yang tidak mereka ketahui mereka malah menghancurkan masa depannya, apalagi remaja yang tidak dapat pendidikan seks dari orang tua, tidak mengetahui akibat dari apa yang telah dilakukannya. ${ }^{7}$

\footnotetext{
${ }^{7}$ Sumiati, Kesehatan Jiwa Remaja dan Konseling, Jakarta; Trans Info Media, 2009. Hlm 23.
} 
Kalangan remaja pada umumnya lebih sensitif menyerap struktur pergaulan bebas dalam kehidupan masyarakat. Pengaruh penyimpangan seksual semacam homoseksual, menurut ahli jiwa adalah tidak adanya keinginan melangsungkan perkawinan. Sedangkan bagi suami isteri yang bekerja di luar rumah, tidak mustahil semakin banyak meninggalkan norma-norma dan tradisi keluarga sebelumnya, kemudian dituntut untuk menyesuaikan diri dalam sistem pergaulan baru, termasuk dengan lawan jenis dalam peroses penyelesaian pekerjaan.

Dalam sosiologi, kejahatan disebabkan karena kondisi-kondisi dan proses-proses sosial yang sama, yang menghasilkan perilaku-perilaku sosial lainnya. Analisis terhadap kondisi dan proses-proses tersebut menghasilkan dua kesimpulan, pertama terhadap hubungan antara variasi angka kejahatan dengan variasi organisasiorganisasi sosial dimana kejahatan tersebut terjadi. Kedua, para sosiolog berusaha untuk menentukan proses-proses yang menyebabkan seseorang menjadi penjahat. Beberapa ahli menekankan pada beberapa bentuk proses seperti imitasi, pelaksanaan peranan sosial, kompensasi, identifikasi, konsepsi diri pribadi, dan kekecewaan yang agresif sebagai proses yang menyebabkan seseorang berperilaku jahat.

\section{Kajian Secara Sosiologis Terhadap Perilaku Kejahatan dan Penyimpangan Seksual di Masyarakat}

Kecenderungan seksual terhadap anak kecil atau Paedofilia, kerap menjadi kasus kejahatan yang berujung mengenaskan bagi para korbannya. Kejadian yang sempat merebak adalah kasus pencabulan siswa oleh guru asing mereka di Jakarta Internasional School (JIS). Berdasarkan hasil penyelidikan, fakta bahwa para pelaku penyimpangan seksual tersebut memiliki penyimpangan perilaku akibat kekerasan seksual yang pernah dia alami saat masih kecil. Misalnya pada kasus dua anak dibawah umur yang terjadi di Jember. "Pada saat ia menjadi santri, tersangka mengaku kerap menjadi korban kekerasan seksual rekan-rekannya sesama santri” Kata AKBP Sabilul Alif. ${ }^{8}$ Pengalaman pahit itulah, yang akhirnya mengakibatkan sekembalinya dari pesantren menjadi pelaku pelecehan seksual kepada sejumlah anak-anak yang masih dibawah umur, yang tingal dilingkungan sekitar rumah pelaku.

Pandangan ilmu sosiologi cukup signifikan dalam memetakan berbagai bentuk penyimpangan perilaku dan reaksi masyarakat yang ditimbulkannya. Kajian tentang perilaku menyimpang dipelajari oleh

\footnotetext{
8 Sholih, Mahrus. (2016, 03, 24). Pelaku pencabulan balita pernah menjadi korban kekerasan seksual. Diakses pada bulan November, 20, 2018. web: https://www.jatimtimes.com/baca/138671/20160324/081359/pelakupencabulan-balita-pernah-menjadi-korban-kekerasan-seksual/
} 
sosiologi karena berkaitan dengan pelanggaran terhadap norma-norma sosial dan nilai-nilai kulutral yang telah ditegakkan oleh masyarakat. Selain itu, melalui teori dan hasilhasil penelitian yang dikembangkannya, sosiologi membantu masyarakat untuk dapat menggali akar-akar penyebab terjadinya tindakan menyimpang. Dalam memahami sebab-sebab dan latar belakang seseorang atau sekelompok orang berperilaku menyimpang, dapat dilihat dari perspektif individualistik dan dapat juga dilihat dari teori-teori sosiologi.

Teori-teori individualistik berusaha mencari penjelasan tentang munculnya tindakan menyimpang melalui kondisi yang secara unik mempengaruhi individu seperti warisan genetis-biologis atau pengalamanpengalaman awal dari kehidupan seseorang di dalam keluarganya. Sedangkan teori-teori yang berspektif sosiologis tentang penyimpangan, akan berupaya menggali kondisi-kondisi sosial yang mendasari penyimpangan perilaku obyek. Menurut Soerjono Soekanto, ${ }^{9}$ beberapa hal yang dianggap bersifat sosiologis dalam memahami tindakan menyimpang misalnya proses penyimpangan yang ditetapkan oleh masyarakat; bagaimana faktor-faktor kelompok berpengaruh terhadap terjadinya perilaku menyimpang pada seseorang; dan reaksi-reaksi apa yang diberikan oleh masyarakat ada orang-orang yang dianggap menyimpang dari norma-norma sosialnya. Teori-teori sosiologi berikut akan penulis gunakan sebagai pisau analisis tinjauan perilaku penyimpangan seksual yaitu sebagai berikut :

\section{Teori Anomie}

Anomie adalah perilaku tanpa arah adan apatis atau keadaan masyarakat yang ditandai oleh pandangan sinis (negatif) terhadap system norma, hilangnya kewibawaan hukum, dan disorganisasi hubungan antara manusia, atau suatu gejala ketidakseimbangan psikologis yang dapat melahirkan perilaku menyimpang dalam berbagai manifestasi..

Menurut penulis, perubahan sosial dalam masyarakatlah yang menimbulkan berbagai dampak perubahan perilaku dalam masyarakat, tergantung kesiapan masyarakat yang bersangkutan dalam menghadapi perubahan-perubahan tersebut. Jika masyarakat siap akan perubahanperubahan kebudayaan yang terjadi, maka akan membawa kemajuan besar bagi masyarakat tersebut. Sebaliknya, jika tidak siap akan perubahan maka akan terjadi ketidakharmonisan dalam kehidupan bermasyarakat. Dalam hal ini dapat dicontohkan dengan kemajuan tekhnologi yang semakin pesat dan

9 Soekanto Soerjono, Op. Cit. Hlm. 127. 
canggih dengan adanya film-film porno yang dapat diakses di media online, bukubuku, maupun majalah porno, sehingga jika pribadi yang tidak siap akan melakukannya melalui cara-cara yang tidak sah, di antaranya melakukan kejahatan atau penyimpangan seksual seperti lesbian, homoseksual, pedophilia, kumpul kebo dan lain sebagainya.

\section{Teori Sosialisasi}

Edwin H. Sutherland yang menamakan teorinya dengan differential association, menurut teori ini penyimpangan adalah konsekuensi dari kemahiran dan penguasaan atas suatu sikap atau tindakan yang dipelajari dari norma-norma yang menyimpang, terutama dari subkultur atau diantara teman-teman sebaya yang menyimpang.

Perilaku menyimpang adalah hasil dari proses belajar atau yang dipelajari, ini berarti bahwa penyimpangan bukan diwariskan atau diturunkan, bukan juga hasil ari intelegensi yang rendah atau karena kerusakan otak. Perilaku menyimpang dipelajari oleh seseorang dalam interaksinya dengan orang lain secara intens. Seseorang menjadi menyimpang karena ia menganggap lebih menguntungkan untuk melanggar norma daripada tidak. Terbentuknya asosiasi diferensial itu bervariasi tergantung dari frekuensi, durasi, prioritas dan intensitas. Jika kasus-kasus penyimpangan seksual diatas dikaitkan dengan differential association, masalah penyimpangan seksual juga dapat diakibatkan dari pengetahuan perilaku jahat dipelajari dalam interaksi dengan orang-orang lain lain, dan orang tersebut mendapat perilaku jahat sebagai hasil interaksi yang dilakukannya dengan orang-orang yang berperilaku dengan kecenderungan melawan norma-norma hukum. Dapat penulis garis bawahi apabila seseorang menjadi jahat, hal itu disebabkan orang tadi mengadakan kontak dengan polapola perilaku jahat dan juga karena dia mengasingkan diri pada pola perilaku yang tidak menyukai kejahatan tersebut. Selanjutnya, bahwa bagian pokok dari perilaku jahat atau kejahatan tadi dipelajari dalam kelompok kecil yang bersifat intim. Begitu juga alat komunikasi tertentu seperti buku, surat kabar, film, televisi, radio, juga tidak kalah juga media online atau internet, memberikan pengaruh-pengaruh tertentu yaitu dalam memberikan sugesti kepada orang perorangan untuk menerima atau menolak perilaku jahat tersebut. Teori ini menentang bahwa tidak ada tingkah laku jahat yang diturunkan dari kedua orangtuanya. Pola perilaku jahat tidak diwariskan tetapi dipelajari melalui suatu pergaulan yang akrab. Hal ini dapat dicontohkan, bahwa para pelaku penyimpangan seksual tersebut memiliki 
penyimpangan perilaku bisa diakibatkan karena kekerasan seksual atau trauma masa lalu yang pernah dia alami saat masih kecil, atau pernah menyaksikan adegan porno dalam video, internet, ponsel, bacaa yang berbau pornografi, atau apabila orang-orang disekitarnya banyak yang berperilaku menyimpang sehingga memicu timbulnya perilaku seks menyimpang, dan mereka merasa hal tersebut adalah pola perilaku normal dan biasa.

3. Teori Labeling (pemberian cap atau teori reaksi masyarakat)

Labeling ini dapat berupa pemberian julukan, cap, etiket yang karena adanya label tersebut maka sang pelaku mengidentifikasikan dirinya sebagai penyimpang dan mengulangi lagi penyimpangan tersebut menjadi suatu kebiasaan atau gaya hidup bagi pelakunya. Schrag menyimpulkan asumsi dasar teori labeling sebagai berikut:

a. Tidak ada suatu perbuatan yang terjadi dengan sendirinya bersifat criminal.

b. Rumusan atau batas tentang kejahatan dan penjahat dipaksakan sesuai dengan kepentingan mereka yang memiliki kekuasaan. c. Seseorang menjadi penjahat bukan karena melanggar ia undang-undang, melakukan karena ia ditetapkan demikian oleh penguasa.

d. Sehubungan dengan kenyataan bahwa seriap orang dapat berbuat baik dan tidak baik, tidak berarti bahwa mereka dapat dikelompokkan menjadi dua bagian: kelompok criminal dan noncriminal.

e. Tindakan penangkapan merupakan awal dari proses labeling.

f. Penangkapan dan pengambilan keputusan dalam system peradilan pidana adalah fungsi dari pelaku/penjahat sebagai lawan dari karakteristik pelanggarannya.

g. Usia, tingkat sosial-ekonomi, dan ras merupakan karakteristik umum pelaku kejahatan yang menimbulkan perbedaan pengambilan keputusan dalam system peradilan pidana.

h. Sistem peradilan pidana dibentuk berdasarkan perspektif kehendak bebas yang memperhatikan penilaian dan penolakan terhadap penjahat.

i. Labeling merupakan suatu proses yang akan melahirkan identifikasi dengan citra sebagai deviant sebagai subculture serta menghasilkan rejection of the rejector. ${ }^{10}$

\footnotetext{
${ }^{10}$ Diakses pada tanggal 5 Agustus 2018, http://mylegalnote.blogspot.co.id/2015/08/resume-teori-labeling-teoridan-kapita.html
} 
Berdasar teori labeling ini, penulis melakukan pendekatan dengan melihat persoalan tentang bagaimana dan mengapa seseorang memperoleh cap atau label. Masyarakat memberi cap atau label buruk terhadap penyimpangan perilaku seksual misalnya pada homoseksual karena perilaku yang disebutkan diatas melanggar normanorma yang ada di masyarakat seperti norma kesusilaan, norma kesopanan, dan norma agama, sehingga jelas masyarakat menolak perilaku tersebut. Setelah mendapat cap atau label dari masyarakat, biasanya pelaku penyimpangan seksual menerima dan menentukan bagaimana mereka selanjutnya bertindak. Pelaku akan mulai berperilaku selaras dengan cap atau label itu dengan konsekuensi terganggunya hubungan-hubungan atau interaksi mereka dengan keluarga bahkan masyarakat di sekitarnya. Dengan cap atau label tersebut, Pelaku penyimpangan seksual akan mencoba melihat dirinya secara mendasar sebagai criminal terutama saat orang disekitarnya memanggil dengan cap atau sebutan orang jahat. Selain menyebabkan terganggunya hubungan secara konvensional dengan masyarakat, pelaku kemungkinan besar juga susah mendapat pekerjaan sehingga mungkin akan mempercayai kejahatan tersebut adalah jalan hidup dan mulai menciptakan hubungan dengan orang-orang yang memiliki nasib yang sama.

\section{Teori kontrol}

Teori kontrol dilatarbelakangi bahwa penyimpangan merupakan hasil dari kekosongan kontrol atau pengendalian sosial atas dasar pandangan bahwa setiap manusia cenderung untuk tidak patuh pada hukum atau memiliki dorongan untuk melakukan pelanggaran hukum. Oleh sebab itu teori ini menilai perilaku menyimpang adalah konsekuensi logis dari kegagalan seseorang untuk mentaati hukum.

Jika dikaitkan dengan teori tersebut, maka apabila lembaga control sosial dalam masyarakat tidak berfungsi maksimal maka akan mengakibatkan melemahnya ikatan sosial anggota masyarakat dengan masyarakat secara keseluruhan sehingga seseorang yang terlepas dari ikatan sosial dengan masyarakatnya akan cenderung berperilaku bebas dan leluasa untuk melakukan penyimpangan,

Tindakan hukum yang tegas harus diberikan pada pelaku tindak kekerasan seksual termasuk pelaku sodomi. Selain itu, para korban kekerasan seksual harus segera diberikan terapi, agar tidak melahirkan pelaku-pelaku kekerasan seksual baru. Hal yang perlu dilakukan agar seseorang tidak menjadi pelaku kekerasan seksual atau pelaku sodomi di 
kemudian hari. Oleh karena itu dibutuhkan penanganan yang berbeda bagi pelaku penyimpangan seksual tersebut demi tercapainya salah satu tujuan pemidanaan yaitu memasyarakatkan narapidana sehingga dapat kembali diterima oleh masyarakat dan tidak mengulangi kembali perbuatannya (residivis).

\section{Solusi Terhadap Perilaku Kejahatan dan Penyimpangan Seksual Ditinjau dari Pandangan Sosiologis dan Pengaturannya dalam Hukum Positif Indonesia}

Setiap manusia mempunyai sifat, watak, dan kehendak sendiri-sendiri yang seringkali bertentangan, sehingga menimbulkan pertikaian. Apabila ketidakseimbangan tersebut dibiarkan, maka akan terjadi perpecahan dalam masyarakat. Interaksi sosial dalam masyarakat tersebut, apabila terus dilanjutkan maka akan membentuk suatu ikatan sosial yang akhirnya mendasari bahwa adanya kaedah-kaedah, norma-norma ataupun peraturan-peraturan hidup yang bersifat mengatur dan memaksa untuk menjamin tertib masyarakat yang dinamakan peraturan atau kaedah hukum itu penting dan harus ada dalam kehidupan bermasyarakat.

Penulis berpendapat, Menjauhkan anakanak dari segala hal yang berbau pronografi adalah hal penting yang harus dilakukan para orang tua. Banyaknya perilaku seksual yang dapat menyimpang dari norma-norma yang telah ada, membuat para pihak harus melakukan berbagai langkah pencegahan dan tindakan untuk mengatasi penyimpangan seksual tersebut. Langkah pencegahan (preventif) dan penindakan (represif) dapat dilakukan mulai dari peran orang tua dan pendidik, hubungan pertemanan, lingkungan masyarakat baik tokoh masyarakat maupun tokoh agama, dan lain sebagainya. Cara-cara tersebut akan diuraikan dalam paragraf selajutnya.

Cara-cara preventif pertama, yaitu dapat dilakukan oleh orang tua yang berperan sebagai control pertama terhadap perilaku anggota keluarga terutama anak-anaknya. Control pertama ini sangat penting karena perkembangan teknologi yang semakin canggih lebih memudahkan anak-anak dan remaja mengakses informasi yang salah tentang perilaku seks bebas, misalnya dengan banyaknya situs-situs porno yang tersebar di media internet. Cara preventif dapat diwujudkan dengan hal-hal seperti: orang tua harus menciptakan cara baru dalam menyampaikan pemahaman seks terhadap anak-anak remaja mereka, membentengi diri anak dengan pendidikan agama yang cukup, mengajak anggota keluarga untuk selalu meningkatkan iman dan taqwa, menjelaskan gambaran bahaya yang terjadi setelah melakukan hubungan seks usia muda/pra nikah, mengamati/memperhatikan perubahan sikap dan perilaku anak, mengisi waktu luang mereka dengan hal-hal positif misalnya yang 
berhubungan dengan bakat dan minat anak dan lain sebagainya.

Kedua, yaitu peran yang dapat dilakukan guru atau pendidik di lingkungan pendidikan anak-anak yaitu antara lain dengan memberi pengetahuan tentang sistem reproduksi manusia, pendekatan terhadap peserta didik dengan member gambaran bahaya hubungan seksual usia muda atau pra nikah, menjadwalkan razia kelas, mengamati dan memberi bimbingan kepada peserta didik yang terlihat menyimpang, melakukan koordinasi yang baik dengan orang tua peserta didik dan lain sebagainya.

Ketiga, yaitu tindakan preventif yang berhubungan dengan hubungan pertemanan antara lain dengan, membentengi diri sendiri dengan pengetahuan agama, melakukan interaksi dengan menghindari berbagai hal yang berkaitan dengan sentuhan fisik atau tubuh, pengendalian diri sendiri dalam hubungan dengan teman yang berbeda jenis kelamin atau pacar, tidak minum minuman keras atau beralkohol, dan lain sebagainya.

Keempat, yaitu peran masyarakat termasuk pula tokoh masyarakat dan tokoh agama di lingkungannya juga sangat diperlukan dalam mengatasi penyimpangan seksual ini. Tindakan yang dapat dilakukan misalnya dengan memberikan sosialisasi kepada masyarakat tentang maraknya penyimpangan sosial termasuk penyimpangan seksual yang saat ini banyak terjadi, meningkatkan keamanan dan kewaspadaan lingkungan dengan melaporkan segala sesuatu yang mencurigakan, terutama terhadap orang lain atau bukan warga setempat, mengadakan pertemuan rutin warga untuk membahas permasalahan-permasalahan di lingkungannya, mengembangkan nilai moral dan norma adat yang ada di lingkungannya, dan lain sebagainya.

Roni Wijayanto dalam bukunya mengutip pendapat Soedarto yaitu, hukum pidana secara umum ditanggapi sebagai semua peraturan yang dibuat oleh yang berwenang dengan tujuan mengatur tata kehidupan bermasyarakat yang berupa larangan dan bersifat memaksa, di mana penjatuhan pidana diberikan kepada seseorang yang melanggarnya. Menurutnya bahwa hukum pidana memuat aturan-aturan hukum yang mengikatkan kepada perbuatan-perbuatan yang memenuhi syarat tertentu akibat yang berupa pidana. ${ }^{11}$ Hukuman dibuat untuk mencegah timbulnya pelanggaran aturan dan menimbulkan efek jera agar para pelakunya tidak lagi mengulangi perbuatan serupa dan tidak terlepas dari nilai keadilan yang utama.

Penyimpangan seksual seperti LGBT justru melanggar hak asasi manusia, Dasar Negara Pancasila dan UUD 1945. Perilaku seksual hanya diwadahi dalam suatu ikatan perkawinan berdasarkan Undang-Undang

11 Wijayanto Roni, (2012), Asas-Asas Hukum Pidana Indonesia, Bandung ; Mandar Maju, Hlm. 
Nomor 1 Tahun 1974, yang jelas tujuannya adalah untuk membentuk keluarga yang kekal berdasarkan Ketuhanan Yang Maha Esa. Sehingga perilaku LGBT seperti perzinahan, seks bebas, hubungan sesama jenis menghilangkan sisi kemanusiaan yang dikaruniakan Tuhan dan juga bertolak belakang dengan Pancasila, sehingga perilaku ini sudah dapat dikategorikan sebagai penyakit psikologis tertentu.

Berdasarkan hukum positif Indonesia, LGBT dan segala penyimpangan seksual dibedakan menjadi kejahatan seksual dan penyimpangan seksual, dimana kejahatan seksual serta zina bagi yang sudah dalam ikatan perkawinan mendapatkan saksi pidana, sedangkan penyimpangan seksual bagi yang belum terikat perkawinan tidak dikenakan sanksi pidana apapun. Untuk orang yang belum menikah tidak dapat dikenakan perzinahan pasal 284 KUHP. Jadi tidak mengherankan kalau di Negara ini sangat banyak muda-mudi yang melakukan seks bebas dengan sesuka hatinya.

Zina adalah persetubuhan yang dilakukan oleh laki-laki atau perempuan yang sudah kawin, dengan perempuan atau laki-laki yang bukan istri atau suaminya. Pasal 284 ayat (1) KUHP tentang perzinahan yaitu dihukum penjara selam-lamanya sembilan bulan, bagi laki-laki yang beristri, berbuat zina sedang diketahuinya, bahwa Pasal 27 KUH Perdata berlaku padanya. Perempuan bersuami yang melakukan zina, Atau laki-laki yang turut melakukan perbuatan itu sedang diketahuinya bahwa kawannya itu bersuami, atau perempuan yang tiada bersuami yang turut melakukan perbuatan itu, sedang diketahuinya bahwa kawannya itu beristri dan Pasal 27 KUHPerdata berlaku pada kawannya. Pengaturan persetubuhan dilakukan dengan paksaan diatur dalam KUHP (Pasal 285), persetubuhan dengan perempuan dalam keadaan pingsan dan tidak berdaya (Pasal 286), sedangkan persetubuhan dengan perempuan belum cukup umur diatur dalam Pasal 287. Perkosaan yang diatur dalam Pasal 285 KUHP yang merupakan adalah delik biasa, dan bukan delik aduan, sehingga perkara dapat diproses tanpa adanya persetujuan dari pihak yang dirugikan (korban), sehingga meskipun korban telah mencabut laporan pada polisi, penyidik tetap berkewajiban melanjutkan perkara tersebut.

Pemerintah telah mengesahkan Peraturan Pemerintah Pengganti Undang-Undang Nomor 1 Tahun 2016 tentang perubahan kedua Undang-Undang Nomor 23 tahun 2002 yang sebelumnya telah diperbarui dalam Undang-Undang Nomor 35 Tahun 2014 tentang Perlindungan Anak. Salah satu isi Perpu tersebut mengatur hukuman kebiri bagi pelaku pelecehan seksual terhadap anak. Pelaku atau mereka yang akan dikebiri itu telah disebutkan secara teknis dalam Pasal 81 Perpu Perlindungan Anak yaitu pada Pasal 81 ayat 7 dihubungkan dengan Pasal 81 ayat 3, 4, dan 5. Pelaku yang dimaksud adalah 
mereka yang termasuk dalam pendidik anak, pengasuh anak, aparat perlindungan anak, anggota keluarga, dan masyarakat sipil yang melakukan pelecehan seksual bersama-sama. Syarat pelaksanaan sanksi kebiri itu harus dipenuhi, pertama yaitu, mereka sudah melakukan kejahatan seksual terhadap anak secara berulang sesuai ayat 4 . Kedua, pelaku menyebabkan korban terluka berat, sakit jiwa, terkena penyakit menular, terganggu alat reproduksinya, atau meninggal seperti yang telah diatur dalam ayat 5 .

\section{KESIMPULAN}

1. Perilaku menyimpang dapat di analisis menggunakan teori-teori sosiologi yang menjelaskan penyebab terjadinya penyimpangan seksual, memperjelas pengertian hukum dan segala sesuatu yang berdiri di belakang gejala-gejala ketertiban umum dalam masyarakat sebagai sumbangsih para penegak hukum untuk mengevaluasi efektivitas berlakunya hukum di masyarakat. Teori yang digunakan, diantaranya :

- Teori Anomie adalah perilaku tanpa arah dan apatis atau keadaan masyarakat yang ditandai oleh pandangan negatif terhadap sistem norma, hilangnya kewibawaan hukum, dan disorganisasi hubungan antara manusia, atau suatu gejala ketidakseimbangan psikologis yang dapat melahirkan perilaku menyimpang dalam berbagai manifestasi.

- Teori Sosialisasi bahwa apabila seseorang menjadi jahat, disebabkan orang tersebut mengadakan kontak dengan pola-pola perilaku jahat dan juga karena mengasingkan diri pada pola perilaku yang tidak menyukai kejahatan tersebut. Selanjutnya, perilaku jahat atau kejahatan tadi dipelajari dalam kelompok kecil yang bersifat intim.

- Teori labeling, melakukan pendekatan dengan melihat persoalan tentang bagaimana dan mengapa seseorang memperoleh cap atau label.

- Teori control, maka apabila lembaga control sosial dalam masyarakat tidak berfungsi maksimal maka akan mengakibatkan melemahnya ikatan sosial anggota masyarakat dengan masyarakat secara keseluruhan sehingga cenderung berperilaku bebas dan leluasa untuk melakukan penyimpangan.

2. Solusi penanganan masalah penyimpangan seksual dapat dilakukan dengan cara preventif oleh peran orang tua sebagai control pertama, guru atau pendidik di lingkungan pendidikan, tindakan preventif yang berhubungan dengan hubungan pertemanan, dan peran masyarakat termasuk tokoh masyarakat dan tokoh agama. Sedangan cara represif 
dalam KUHP yaitu Perzinahan pasal 284 KUHP, Persetubuhan Pasal 285, persetubuhan dengan perempuan dalam keadaan pingsan dan tidak berdaya Pasal 286, dan persetubuhan dengan perempuan belum cukup umur pada Pasal 287, Peraturan Pemerintah Pengganti UndangUndang Nomor 1 Tahun 2016 tentang perubahan kedua Undang-Undang Nomor 23 tahun 2002 yang sebelumnya telah diperbarui dalam Undang-undang Nomor 35 Tahun 2014 tentang Perlindungan Anak.

\section{DAFTAR PUSTAKA}

\section{Perundang-undangan}

Undang-Undang Nomor 35 Tahun 2014 tentang Perlindungan Anak.

\section{Buku}

Katjtaasungkana, (2006), Penyalahan

Seksual Pada Anak, Jakarta ;Mitra

Kencana

Koenig Samuel, (1957), Man and Society, New York ; Baners \& Nobel inc

Moeljatno, (2005), Kitab Undang-undang Hukum Pidana (KUHP), Jakarta: Bumi Aksara

Saifullah, (2010), Refleksi Sosiologi Hukum, Bandung; Rafika Aditama

Simandjutak B. Dan Pasaribu, (1989), Kriminologi, Jakarta ; Tarsito

Sulistiani,Sisca, Lis, (2016), Kejahatan dan Penyimpangan Seksual, Bandung; Nuansa Aulia
Sumiati, (2009), Kesehatan Jiwa Remaja dan Konseling, Jakarta ; Trans Info Media

Soerjono Soekanto, (2007), Sosiologi Suatu Pengantar, Jakarta ; Rajawali Pers

Wijayanto, Roni, (2012), Asas-Asas Hukum Pidana Indonesia, Mandar Maju ; Bandung

Zainuddin, (2005), Sosiologi Hukum, Jakarta ; Sinar Grafika

\section{Internet}

Sholih, Mahrus. (2016, 03, 24). Pelaku pencabulan balita pernah menjadi korban kekerasan seksual. Diakses pada bulan November, 20, 2018. website : https://www.jatimtimes.com/baca/13867 1/20160324/081359/pelaku-pencabulanbalita-pernah-menjadi-korbankekerasan-seksual/ 